\title{
Prostate volume and its relationship with anthropometric variables among different ethnic groups of South-Kivu, DR Congo
}

\author{
L. E. Mubenga ${ }^{1,2^{*}} \mathbb{D}$, M. P. Hermans ${ }^{3}$, D. Chimanuka' ${ }^{1}$ L. Muhindo ${ }^{1}$, E. Bwenge ${ }^{4,5}$ and B. Tombal ${ }^{6}$
}

\begin{abstract}
Background: The prevalence of benign prostate hyperplasia (BPH) varies among individuals from different races or ethnic groups. South-Kivu province (DR Congo) has several morphologically different ethnic groups. Our aim was to compare prostate volume and assess its possible association with specific anthropometric measurements among major ethnic groups.
\end{abstract}

Methods: This is a cross-sectional study of male subjects, $\geq 40$ year old, enrolled in 10 different sites of South-Kivu allowing both easy access and ethnic diversity. We compared urological features, anthropometric parameters, and body fat composition among 979 subjects who met study criteria: Shi ( $n: 233)$, Lega ( $n: 212)$, Havu (n: 204), BembeFuliru (n: 172), and minority ethnic groups ( $n: 158)$.

Results: Prostate volume was statistically different among ethnic groups. Median (interquartile range) size of prostate gland was significantly larger in Lega: $55(38-81) \mathrm{cc}$, and smaller in Havu, $20(17,24) \mathrm{cc} ; p<0.001$. Overall, an enlarged prostate ( $\geq 30 \mathrm{cc}$ ) was documented in $91 \%$ of Lega men, in $59 \%$ of intermediate class men (Shi, Bembe-Fuliru, others), and in a mere $11 \%$ of Havu men. In multivariate analysis, prostate volume was significantly associated with age $(p<0.001)$, ethnic group $(p<0.001)$, residence $(p: 0.046)$, and fasting blood glucose ( $p$ : 0.001). Conversely, prostate volume was neither associated with anthropometric parameters, nor with body fat composition.

Conclusion: Prostatic size varies widely among men from different ethnic origins in South-Kivu. Different genetic determinants and cellular composition of prostatic gland could represent risk factors that need to be examined in forthcoming studies.

Keywords: Prostate volume, Ethnic groups, Anthropometric parameters, Body fat, South-Kivu

\section{Background}

Prostate volume is modulated by numerous factors, the best documented being aging and androgen levels [1]. The prevalence of benign prostate hyperplasia $(\mathrm{BPH})$ varies widely among individuals from different races or ethnicities [2].

\footnotetext{
*Correspondence: leonmubenga@yahoo.fr; emmanuelmubengalm@gmail. com

${ }^{1}$ Department of Urology, Université Catholique de Bukavu (UCB), 02,

Michombero Street, Bukavu, Democratic Republic of Congo

Full list of author information is available at the end of the article
}

However, most of the available literature describes separately associations between $\mathrm{BPH}$ and anthropometrics [3-5], or ethnicity [2, 6, 7].

Genetic and parental factors, cellular prostatic composition, socioeconomic status, and dietary habits vary considerably among different ethnic groups and are considered as additional risk factors for prostate enlargement [6-14].

The province of South-Kivu (DR Congo) is inhabited by many ethnic groups that differ in sociocultural as well as anthropo-morphological and geographical parameters [15-20]. 
This study aimed to compare the prostatic volume in major representative ethnic groups of South-Kivu and assess its possible association with anthropometric parameters and body fat composition to document candidate risk factors for prostate enlargement specific to that area.

\section{Methods}

\subsection{Study population}

South-Kivu province has 13 major ethnic groups among which the most numerically important are the Shi, Lega, Havu, Fuliru, and Bembe. These groups differ by culture, dietary habits, geographical location, and morphological characteristics [15-22].

\subsection{Data collection}

The screening team visited 10 different sites given their ease of access, security, and ethnic diversity. Advertisement for the prostate screening project was made on local radios, using posters, and during worship ceremonies in churches, with announcements made by officiants 6 weeks prior to data gathering.

The recruitment of participants was based on opportunity sampling. Men $\geq 40$ years of age were offered free prostatic screening, research team members having settled in major local urban hospitals and stayed for at least three days at each center.

The language used in the field was Swahili, since it is the commonest language in this part of Eastern DR Congo. Trained physician examiners used a structured questionnaire to gather ethno-tribal data, as well as medical history collection, urological scores [International Prostate Symptom Score (IPSS), quality of life score (QOL)], and duration of urological symptoms.

The French versions of the IPSS and QOL scores were translated into Swahili by a panel of professional translators. The translated versions were successively tested on an arbitrary sample of 50 subjects to ensure a good understanding of the different points addressed.

Fasting blood was collected, and each participant had a clinical examination, including blood pressure measurement, anthropometric parameters (body weight, height, and waist circumference), and body fat composition (fat mass, visceral fat) using a bioelectrical tetrapodal body fat analyzer OMRON BF 508 impedance meter. The fat mass categorization and visceral fat scale were provided in the manufacturer's manual.

The conicity index $(\mathrm{CI})$, which evaluates the statural distribution of body fat, was calculated using the Valdez formula [23, 24]:

$$
\mathrm{CI}=\frac{\mathrm{WC}}{0.109 \times \sqrt{W / H}}
$$

$\mathrm{WC}=$ waist circumference (m); $W$ weight $(\mathrm{kg}) ; H$ height (m); 0.109: constant.

A cutoff of 1.25 was used to classify $\mathrm{CI}$ into normal and high categories [24].

Urological features of BPH were assessed from lower urinary tract symptoms severity, peak flow rates at uroflowmetry, post-voiding residual (PVR) urine volume measured by suprapubic ultrasonography, and prostate volume (PV) estimated by pelvic ultrasonography.

Men with a prostate volume $\geq 30 \mathrm{cc}$ were considered to have an enlarged gland [25-27]. The prostate volume was categorized as follows: $<30 \mathrm{cc}$ (normal volume), 30-60 cc (moderately high volume), and $>60 \mathrm{cc}$ (very high volume).

Subjects with a medical history of prostate surgery, ongoing medication(s) for $\mathrm{BPH}$, prostate abnormality on digital rectal examination (DRE), and/or pelvic ultrasonography, suggesting prostate cancer or prostatitis, were excluded from the study.

\subsection{Statistical analyses}

Statistical analyses were carried on using Stata 14. Categorical data were summarized into frequencies and proportions. The distribution of continuous data was assessed graphically and statistically. Normally distributed data are reported as means with standard deviations (SD), while medians with interquartile ranges (IQR) were used for reporting non-Gaussian data.

The bivariable association between dependent and independent variables was examined using analysis of variance (ANOVA) for Gaussian data. When assumptions of normality or equality of variances were not met, a Kruskal-Wallis rank test was used. Variables were selected in the multivariable regression model based either on a $p$ value below $\leq 0.2$ and/or on biological plausibility. We report the $\beta$-coefficients (average expected mean differences) with $95 \%$ confidence intervals (CIs) as measure of association. The significance level for all the analyses was set to an $\boldsymbol{\alpha}$ type 1 error value $<5 \%$.

\subsection{Ethics}

Informed consent was obtained from each participant, and the study protocol was approved by the local ethical committee.

\section{Results}

Data were obtained from 979 subjects from five ethnic groups. There was no significant difference regarding age between ethnicities. However, prostatic volume was statistically different among ethnic groups. Average 
prostate gland size was significantly larger in Lega men, and smaller in Havu men. Urological features of the studied population are listed in Table 1.

Obesity markers including waist circumference, BMI, body fat, and visceral fat were significantly higher in Bembe-Fuliru men, whereas metabolic correlates of BPH (conicity index and fasting glucose) were significantly higher in Lega men. There was no statistical difference in blood pressure between groups (Table 2).

About prostatic volume, Lega and Havu men showed the greatest ethnic difference, and the other ethnic groups were intermediate in size.

Thus, $91 \%$ of Lega men, $59 \%$ of subjects from intermediate ethnicities, and $11 \%$ of Havu men had an enlarged prostate.

In addition, among BPH subjects (prostatic volume $\geq 30 \mathrm{cc}$ ) younger than 60 years $(n=184)$, Lega men amounted to $71(39 \%)$ versus $9(5 \%)$ among Havu men (Table 3).

In unadjusted analysis, prostate volume was associated with age, ethnic group, place of residence, conicity index, BMI, waist circumference, visceral fat, fasting blood glucose, and quality of life score.

However, following adjustment, age, ethnic group, place of residence, and fasting blood glucose were significantly associated with prostatic volume (Table 4).

\section{Discussion}

In this population-based study, we assessed the interrelationships between anthropometric parameters, including body composition, with prostate volume in major ethnic groups of South-Kivu.

Among these groups, the Shi ethnonym [15, 18, 21, 22] concerns the major ethnic group in the province. They are in the center and the western part of the province. The works of Hiernaux [15] in 1953 noted an average height of 163, $5 \mathrm{~cm}$ among male adult Shi individuals. Their habitual diet is varied.

The Lega $[17,19]$ is the second largest group; they live in the southwestern part of the province [19].

The Lega are constitutively of smaller height: $160,4 \mathrm{~cm}$ according to the data of Hiernaux in 1953 [15, 17].

Their diet is saltier, meat-based, and richer in fat. Fish are eaten mostly as salty or smoked.

The Bembe and Fuliru live in Southern Kivu, on a territory neighboring Burundi. Their morphological characteristics are like those of Burundian Hutu. By extrapolation, their average height would approach 165, $9 \mathrm{~cm}$ according to Hiernaux's data $[16,17]$.

Their diet is characterized by low fat and animal proteins intakes and a high proportion of carbohydrates and vegetable proteins, akin to their counterparts in Burundi.

The Havu [16, 20, 21] live in north of the province, mainly along the shores of Lake Kivu and on Idjwi Island.

Table 1 Urological features

\begin{tabular}{|c|c|c|c|c|c|c|c|}
\hline Parameter & All population & SHI & LEGA & HAVU & BEMBE-Fuliru & Others & $p$ value \\
\hline \multirow[t]{2}{*}{ AGE (years) } & n: 979 & $n: 233$ & $n: 212$ & $n: 204$ & n: 172 & $n: 158$ & $.62^{\mathrm{a}}$ \\
\hline & $61.12 \pm 10.7$ & $61.9 \pm 11.06$ & $61.5 \pm 9.8$ & $60.5 \pm 10.8$ & $60.6 \pm 11.12$ & $60.8 \pm 10.4$ & \\
\hline \multirow[t]{2}{*}{ Duration of symptoms (years) } & n: 979 & $n: 233$ & $n: 212$ & $n: 203$ & n: 172 & $n: 157$ & .39 \\
\hline & $2(1,5)$ & $2(1,5)$ & $2(1,4)$ & $2(1,5)$ & $2(1,5)$ & & \\
\hline IPSS & n: 979 & $n: 233$ & $n: 212$ & $n: 204$ & n: 172 & $n: 158$ & .043 \\
\hline$(0-35)$ & $15(5,24)$ & $19(7,27)$ & $15(5,25)$ & $15(5,22)$ & $14(8,20)$ & $15(5,25)$ & \\
\hline QOL score & $n: 979$ & $n: 233$ & $n: 212$ & $n: 204$ & n: 172 & $n: 158$ & .0543 \\
\hline$(1-7)$ & $5(2,6)$ & $6(2,7)$ & $5(2,6)$ & $5(2,6)$ & $5(2,6)$ & $5(2,6)$ & \\
\hline IIEF score & $n: 971$ & $n: 233$ & n: 209 & $n: 200$ & n: 172 & n: 157 & .85 \\
\hline$(0-25)$ & $17(10,23)$ & $16(10,23)$ & $16(10,25)$ & $17(11,25)$ & $15(14,20)$ & $18(11,23)$ & \\
\hline \multirow[t]{2}{*}{ QMAX (mL/s) } & n: 979 & $n: 233$ & $n: 212$ & n: 204 & $n: 172$ & $n: 158$ & $<.001$ \\
\hline & $14(8.9,19.8)$ & $14.3(8.5,21.6)$ & $10.7(7.4,16.8)$ & $15.35(10.05,22.3)$ & $14.7(10.85,19.8)$ & $14.79(9,20.1)$ & \\
\hline \multirow[t]{2}{*}{ Micturition duration (Sec) } & $n: 959$ & $n: 229$ & $n: 204$ & $n: 200$ & $n: 169$ & $n: 157$ & .076 \\
\hline & $17.2(12.8,24.5)$ & $16.6(12.8,22.9)$ & $16.55(12.5,23.4)$ & $16.45(12.55,23.7)$ & $19.1(14,27.2)$ & $18(13,24.3)$ & \\
\hline \multirow[t]{2}{*}{ PVR (mL) } & n: 958 & $n: 228$ & $n: 204$ & $n: 200$ & n: 169 & $n: 157$ & $<.001$ \\
\hline & $5(5,12)$ & $5(5,17)$ & $5(5,5)$ & $5(5,5)$ & $5(5,16)$ & $5(5,15)$ & \\
\hline \multirow[t]{2}{*}{ Prostate volume (cc) } & $n: 979$ & $n: 233$ & $n: 212$ & $n: 204$ & n: 172 & $n: 158$ & $<.001$ \\
\hline & $32(22,49)$ & $33(24,46)$ & $55(38,81)$ & $20(17,24)$ & $30(23,42)$ & $34(24,52)$ & \\
\hline
\end{tabular}

a Comparison was done using ANOVA

IPSS International Prostate Symptoms Score (0-35), QOL score quality of life score (1-7), IIEF score International Index of Erectile Function Score (0-25), QMAX peak uroflowmetry $(\mathrm{mL} / \mathrm{s})$, PVR post-voiding residual $(\mathrm{mL})$ 
Table 2 Anthropometric parameters and metabolic correlates of BPH

\begin{tabular}{|c|c|c|c|c|c|c|c|}
\hline Parameter & All population & SHI & LEGA & HAVU & BEMBE-Fuliru & Other & $p$ value \\
\hline \multirow[t]{2}{*}{ Weight (kg) } & $n: 979$ & $n: 233$ & $n: 212$ & $n: 204$ & n: 172 & n: 158 & $<.001^{\mathrm{a}}$ \\
\hline & $58.17 \pm 11.35$ & $57.9 \pm 12.53$ & $55.94 \pm 10.17$ & $56.73 \pm 9.39$ & $61.68 \pm 12.77$ & $59.59 \pm 10.68$ & \\
\hline \multirow[t]{2}{*}{ Height (m) } & n: 979 & $n: 233$ & $n: 212$ & $n: 204$ & n: 172 & n: 158 & $<.001$ \\
\hline & $1.62(1.57,1.67)$ & $1.63(1.6,1.67)$ & $1.59(1.54,1.62)$ & $1.62(1.57,1.66)$ & $1.64(1.59,1.69)$ & $1.63(1.58,1.68)$ & \\
\hline \multirow[t]{2}{*}{ WC $(\mathrm{cm})$} & n: 979 & $n: 233$ & $n: 212$ & n: 204 & n: 172 & $n: 158$ & $<.001^{\mathrm{a}}$ \\
\hline & $82.73 \pm 11.08$ & $83.17 \pm 12.58$ & $80.89 \pm 10.34$ & $80.93 \pm 8.56$ & $86.18 \pm 12.21$ & $83.08 \pm 10.4$ & \\
\hline \multirow[t]{2}{*}{ BMI $\left(\mathrm{kg} / \mathrm{m}^{2}\right)$} & n: 979 & $n: 233$ & $n: 212$ & $n: 204$ & n: 172 & n: 158 & $.0011^{\mathrm{a}}$ \\
\hline & $22.26 \pm 3.76$ & $21.86 \pm 4.19$ & $22.20 \pm 3.57$ & $21.75 \pm 3.03$ & $23.11 \pm 4.23$ & $22.65 \pm 3.5$ & \\
\hline \multirow[t]{2}{*}{ Conicity index } & n: 979 & $n: 233$ & $n: 212$ & n: 204 & n: 172 & n: 158 & $<.001$ \\
\hline & $1.26(1.20,1.32)$ & $1.29(1.23,1.35)$ & $1.29(1.24,1.36)$ & $1.26(1.20,1.32)$ & $1.22(1.18,1.28)$ & $1.21(1.18,1.27)$ & \\
\hline \multirow[t]{2}{*}{ Systolic BP (mm Hg) } & n: 979 & $n: 233$ & $n: 212$ & $n: 204$ & n: 172 & n: 158 & $.42^{\mathrm{a}}$ \\
\hline & $139.97 \pm 25.03$ & $136.94 \pm 24.29$ & $140.43 \pm 26.64$ & $142.64 \pm 25.48$ & $142.9 \pm 24.52$ & $137.11 \pm 23.29$ & \\
\hline \multirow[t]{2}{*}{ Diastolic BP (mm Hg) } & n: 979 & $n: 233$ & $n: 212$ & $n: 204$ & n: 172 & n: 158 & $.85^{\mathrm{a}}$ \\
\hline & $84.59 \pm 14.90$ & $83.93 \pm 14.82$ & $85.56 \pm 15.43$ & $84.58 \pm 16.32$ & $84.94 \pm 13.05$ & $83.87 \pm 14.35$ & \\
\hline \multirow[t]{2}{*}{$\mathrm{FBG}(\mathrm{mg} / \mathrm{dL})$} & n: 979 & $n: 233$ & $n: 212$ & $n: 204$ & n: 172 & $n: 158$ & $<.001^{\mathrm{a}}$ \\
\hline & $92.68 \pm 12.64$ & $92.13 \pm 12.92$ & $98.16 \pm 12.55$ & $91.11 \pm 10.32$ & $89.42 \pm 11.32$ & $91.7 \pm 14.22$ & \\
\hline \multirow[t]{2}{*}{ BODY FAT (\%) } & n: 979 & $n: 233$ & $n: 212$ & $n: 204$ & n: 172 & $n: 158$ & $<.001$ \\
\hline & $14.3(10,20.4)$ & $12.4(10,20.2)$ & $12.95(10,18.3)$ & $14(10,18.4)$ & $17.8(11,24.05)$ & $15.6(10,20.7)$ & \\
\hline \multirow[t]{2}{*}{ VFS $(0-30)$} & n: 979 & $n: 233$ & $n: 212$ & $n: 204$ & n: 172 & n: 158 & $<.001$ \\
\hline & $5(4,8)$ & $5(4,9)$ & $5(4,8)$ & $5(4,8)$ & $7(5,10)$ & $6(4,8)$ & \\
\hline
\end{tabular}

a Comparison was done using ANOVA

WC Waist circumference $(\mathrm{cm}), B M I$ Body mass index $\left(\mathrm{kg} / \mathrm{m}^{2}\right)$, Systolic BP systolic blood pressure $(\mathrm{mm} \mathrm{Hg})$, Diastolic BP diastolic blood pressure ( $\mathrm{mm}$ Hg), FBG fasting blood glucose (mg/dL), VFS visceral fat score (0-30 scale)

Table 3 Prostate volume by ethnic origin

\begin{tabular}{|c|c|c|c|c|}
\hline \multirow[t]{2}{*}{ Ethnic group } & \multicolumn{3}{|l|}{ Prostate volume } & \multirow[t]{2}{*}{ Total } \\
\hline & Normal (<30 cc) & Moderately high (30-60 cc) & Very high (> $60 \mathrm{cc}$ ) & \\
\hline Havu & $183(89.71 \%)$ & $21(10.89 \%)$ & $0(0 \%)$ & $204(20.84)$ \\
\hline Intermediate group* & $231(41.03 \%)$ & $267(47.42 \%)$ & $65(11.55 \%)$ & $563(57.51)$ \\
\hline Lega & $21(9.91 \%)$ & $95(44.81 \%)$ & $96(45.28 \%)$ & $212(21.65)$ \\
\hline$p$ value & & & & $<.001$ \\
\hline
\end{tabular}

*Shi, Bembe, Fuliru, and other ethnic groups

They are morphologically like Rwandan Tutsi, whose history they share. By nature, Havu individuals are taller; by extrapolation, average height of $176,5 \mathrm{~cm}$ would correspond to that of Rwandan Tutsi.

Their diet is enriched in fresh fish and dairy products. Cattle are a sign of wealth, thus intended for sale or prestige, and livestock is rarely used for meat consumption.

Other tribal groups have intermediate characteristics to these majority groups.

Interethnic marriages produce individuals whose morphological characteristics are the result of those of the two parents, whereas they inherit the paternal ethnonym and accordingly patrilineal sociocultural traits.
This study highlighted a significant variability of prostate volume among South-Kivu ethnic groups regardless of anthropometric parameters and body composition (Tables 1 and 2). In addition, increased prostatic volume was independently associated with ethno-geographic origin (Table 4), confirming previous reports $[5,6,13,28]$.

Among Lega men, prostate volume was significantly larger than in other ethnic groups. Conversely, among Havu men, prostate volume was significantly smaller than in other groups. It was unusual to measure prostate sizes $<30 \mathrm{cc}$ among Lega subjects, and $>20 \mathrm{cc}$ among Havu subjects (Table 3). 
Table 4 Bivariate and multivariate analyses of the association between ethnic groups and prostate volume

\begin{tabular}{|c|c|c|c|c|}
\hline Variable & $\begin{array}{l}\text { Unadjusted mean difference } \\
(95 \% \mathrm{Cl})\end{array}$ & $p$ value & $\begin{array}{l}\text { Adjusted mean difference (95\% } \\
\text { Cl) }\end{array}$ & $p$ value \\
\hline \multicolumn{5}{|l|}{ Ethnic group } \\
\hline Havu & Ref. & & Ref. & \\
\hline Intermediate group* & $16.14(14.37,17.90)$ & $<.001$ & $12.42(9.96,14.88)$ & $<.001$ \\
\hline Lega & $44.46(39.50,49.42)$ & $<.001$ & $41.52(37.09,45.94)$ & $<.001$ \\
\hline \multicolumn{5}{|l|}{ Age } \\
\hline$<60$ years & Ref. & & Ref. & \\
\hline$\geq 60$ years & $11.14(7.92,14.35)$ & .002 & $8.99(6.37,11.61)$ & $<.001$ \\
\hline \multicolumn{5}{|l|}{ Residence } \\
\hline Rural & Ref. & & Ref. & \\
\hline Urban & $8.62(4.35,12.90)$ & $<.001$ & $6.69(2.49,10.89)$ & .002 \\
\hline \multicolumn{5}{|l|}{ Conicity index } \\
\hline Normal $(<1.25)$ & Ref. & & & \\
\hline High $(\geq 1.25)$ & $5.07(1.72,8.41)$ & .003 & $.711(-.82, .24)$ & .363 \\
\hline \multicolumn{5}{|l|}{ BMI $\left(\mathrm{kg} / \mathrm{m}^{2}\right)$} \\
\hline Normal & Ref. & & Ref. & \\
\hline Underweight & $-1.70(-6.71,3.30)$ & $<.001$ & $-3.22(-7.41,0.97)$ & .132 \\
\hline Overweight/obese & $8.54(4.10,12.98)$ & .504 & $5.59(-.64,11.83)$ & .079 \\
\hline \multicolumn{5}{|l|}{$W C(\mathrm{~cm})$} \\
\hline Normal $(<94 \mathrm{~cm})$ & Ref. & & & \\
\hline $\operatorname{High}(\geq 94 \mathrm{~cm})$ & $10.73(5.93,15.53)$ & $<.001$ & $1.65(-3.68,6.98)$ & .54 \\
\hline \multicolumn{5}{|l|}{$\mathrm{FBG}(\mathrm{mg} / \mathrm{dL})$} \\
\hline$<100$ & Ref. & & & \\
\hline$\geq 100$ & $11.11(5.81,16.41)$ & $<.001$ & $6.08(1.68,10.47)$ & .007 \\
\hline
\end{tabular}

*Shi, Bembe, Fuliru, and other ethnic groups

As noted by Colon et al. [6], genetic variations between patients of different ethnicities represent additional modulators for the development of BPH.

Several genetic factors putatively involved in the development of BPH have been extensively studied. One of them is related to androgen receptor cytosin adenosin Guanidin (CAG) repeats $[8,10]$. The frequency of CAG repeats in the androgen receptor (AR) gene was hypothesized to contribute to $\mathrm{BPH}$ incidence. In addition, Mitsumori et al. [8] found an association between short CAG repeat length and larger prostatic gland. Further, altered gene expression was proposed in driving BPH [10]. Luo et al. [29] reported a subset of 76 genes consistently upregulated in $\mathrm{BPH}$ when compared to normal prostate tissue, while Stamey et al. [10] identified 22 genes. These genes are involved at various levels of cell proliferation and growth factors regulation [10].

Interestingly, BPH in men younger than 60 years was overrepresented among the Lega subgroup. Similarly, Patel and Parsons [30] noted that 50\% of patients who underwent surgical treatment for BPH before 60 years of age had an inherited autosomal dominant form of the disease. In addition, these subjects had massively enlarged prostate glands. A genetic cause will be considered even more than BPH occurs in younger patients (under 50 years) [12]. Pearson et al. [31] demonstrated that a strong familial history of early onset and marked prostate enlargement was more likely associated with risk inheritance rather than with symptom severity.

The genetic contribution to BPH is also revealed by cellular composition analysis of prostate cells and/or androgenic expression. Henderson et al. [7] noted a difference in the cellular composition of prostatic biopsies performed in the transition zone among populations from different origins, namely African-Americans, European-Americans, and Japanese. African-Americans had a higher stroma/epithelium ratio. Further, these authors observed variability in dihydrotestosterone (DHT) concentration among subjects of different races. We hypothesize that racial differences in cellular composition of the prostate and DHT concentration could be at play in the variation of prostate parameters among different ethnic groups in the present study.

Conversely, no study has yet been able to demonstrate a protective influence of one or more genes. A study of Mehta and Vezina [32] highlighted the 
potential protective role of aryl hydrocarbon receptor (AHR) signaling in delaying the onset of BPH. They reported the putative mechanisms by which AHRsignaling activation interferes with pathological processes involved in driving $\mathrm{BPH}$.

Similarly, the smaller prostate volume found among Havu subjects in the present study suggests the existence of ethnically derived and likely genetic intrinsic protective factor(s) to prostate enlargement.

Lifestyle and dietary habits contribute substantially to $\mathrm{BPH}$ pathogenesis [33]. Lega peoples are used to consume a fattier and saltier diet, with high amount of red meat, considered as driving up the odds for BPH. Espinosa [14] suggested that dietary patterns associated with increased risks of $\mathrm{BPH}$ include high consumption of starch and red meat. Parsons [34] also suggested that meat and fat consumption were associated with increased odds of BPH. Wang et al. [13] demonstrated the role of diet on difference in prostatic characteristics between Mongolians and Han Chinese. They observed that Mongolian men had a significantly greater consumption of meat, and consequently a higher incidence of intraprostatic chronic inflammation and intraglandular calcification than Han men.

Conversely, Havu subjects live along Lake Kivu and on Idjwi Island. This ethnic group has a high consumption of fresh fish, vegetables, and pulses. They also raise cattle for sale. Vegetables and fruits are known to have protective effects against prostate enlargement. Cold sea fish are also rich in polyunsaturated fatty acids (PUFAs), which also have a beneficial effect on BPH $[35,36]$. We did not assess the amount of PUFAs provided by traditional fishing in the Great African lakes region.

Despite less healthy dietary habits, Lega subjects did not exhibit higher prevalence of obesity markers or body fat, and the anthropometric parameters (height, weight, BMI, waist circumference) and body composition (total fat and visceral fat) were not higher in the Lega group but in the intermediate group consisting of Bembe and Fuliru men (Table 2). Further, none of these parameters were associated with prostate volume in multivariable analyses.

Even though cultural characteristics are more prevalent in rural areas, differences in prostate volume between the two extreme groups (Lega and Havu) were consistent across rural and urban areas.

We consider that either individuals conserved their dietary habits wherever they live or genetics have more influence than dietary variables on determining prostate volume.

\subsection{Study limitations}

This survey has several obvious and theoretical limitations. One is the genetic mixing of populations from interethnic marriages which may produce offspring with intermediate ethnic characteristics. Another is the lack of prostate biopsies to rule out undiagnosed prostate cancer and/or analyze prostatic cellular distribution.

\section{Conclusion}

Our data provide clear evidence of considerable interethnic variability in prostatic size among men living in SouthKivu. Further, prostate volume was neither associated with anthropometric parameters nor with body fat composition. Thus, genetics and adverse modulators of cellular composition of the prostatic gland are candidate risk factors that need further investigation as to their potential role in the pathogenesis of BPH in sub-Saharan Africa.

\section{Abbreviations \\ AHR: aryl hydrocarbon receptor; AR: androgen receptor; BMl: body mass index; BP: blood pressure; BPH: benign prostate hyperplasia; CAG: cytosin adenosin Guanidin; Cl: conicity index; DHT: dihydrotestosterone; DRE: digital rectal examination; FBG: fasting blood glucose; $\mathrm{H}$ : height; IIEF score: International Index of Erectile Function Score; IPSS: International Prostate Symptom Score; IQR: interquartile range; PUFAs: polyunsaturated fatty acids; PV: prostate vol- ume; PVR: post-voiding residual; Qmax: peak uroflowmetry; QOL score: quality of life score; SD: standard deviation; VFS: visceral fat score; W: weight; WC: waist circumference.}

\section{Acknowledgements}

The authors are grateful to the South-Kivu Provincial Health Division, and to the medical staff of host hospitals in Katana, Kalehe, Nyabibwe, Birava, Uvira, Walungu, Luhwinja, Kaziba, Bukavu, and Kamituga for helping to carry out this study.

\section{Authors' contributions}

LEM provided a substantial contribution to conception and design, acquisition of data, and drafting the article. MPH revised critically the manuscript. DC actively participated in documentary research, participants' follow-up, and data collection. LM actively participated in documentary research and data collection. EB performed statistical analyses and interpretation of data. BT assessed the manuscript and provided final approval of the version to be submitted. All authors read and approved the final manuscript.

Funding

This study was funded by research Grants from the "Société Belge d'Urologie" (SBU), and the Vlaamse Interuniversitaire Raad (VLIR).

\section{Availability of data and materials}

Supplementary data to this article are available and can be obtained if needed.

\section{Competing interests}

The authors declare that they have no competing interests.

\section{Consent for publication}

Not applicable.

Ethics approval and consent to participate

The study was approved by the Catholic University of Bukavu Ethics and Research Committee (Reference: UCB/CIE/NC/002/2016). Each participant approved to participate in this study. At each step of the present study, confidentiality and anonymity rules were observed.

\section{Author details}

${ }^{1}$ Department of Urology, Université Catholique de Bukavu (UCB), 02, Michombero Street, Bukavu, Democratic Republic of Congo. ${ }^{2}$ Institut 
Supérieur des Techniques Médicales de Bukavu (ISTM Bukavu), Bukavu, Democratic Republic of Congo. ${ }^{3}$ Division of Endocrinology and Nutrition, Cliniques Universitaires St-Luc and Institut de Recherche Expérimentale et Clinique (IREC), Université Catholique de Louvain, Brussels, Belgium. ${ }^{4}$ Institute of Health and Society - Institut de Recherche Santé et Société (IRSS) School of Public Health, Université Catholique de Louvain, Brussels, Belgium. ${ }^{5}$ Ecole Régionale de Santé Publique, Université Catholique de Bukavu (UCB), Bukavu, Democratic Republic of Congo. ${ }^{6}$ Department of Urology, Université Catholique de Louvain (UCL), Brussels, Belgium.

Received: 13 February 2020 Accepted: 10 June 2020

Published online: 14 September 2020

\section{References}

1. Ozden C, Ozdal OL, Urgancioglu G, Koyuncu H, Gokkaya S, Memis A (2007) The correlation between metabolic syndrome and prostatic growth in patients with Benign Prostatic Hyperplasia. Eur Urol 51:199-206

2. Zeng QS, Xu CL, Liu ZY, Wang HQ, Yang B, Xu WD, Jin TL et al (2012) Relationship between serum sex hormones levels and degree of benign prostate hyperplasia in Chinese aging men. Asian J Androl 14(5):773-777

3. Badmus TA, Asaleye CM, Badmus SA, Takure AO, Ibrahim MH, Arowolo OA (2013) Benign prostate hyperplasia: average volume in southwestern Nigerians and correlation with anthropometrics. Niger Postgrad Med J 20(1):52-56

4. Burke JP, Rhodes T, Jacobson DJ, McGree ME, Roberts RO, Girman CJ, Lieber MM, Jacobsen SJ (2006) Association of anthropometric measures with the presence and progression of Benign Prostatic Hyperplasia. Am J Epidemiol 164:41-46

5. Campbell B (2005) High rate of prostate symptoms among Ariaal men from Northern Kenya. Prostate 62(1):83-90

6. Colon I, Payne RE (2008) Benign prostatic hyperplasia and lower urinary tract symptoms in African Americans and Latinos: treatment in the context of common comorbidities. Am J Med 121:S18-S26

7. Henderson BE, Bernstein L, Ross RK, Depue RH, Judd HL (1988) The early in utero oestrogen and testosterone environment of blacks and whites: potential effects on male offspring. Br J Cancer 57:216-218

8. Mitsumori K, Terai A, Oka H, Segawa T, Ogura K, Yoshida O, Ogawa O (1999) Androgen receptor CAG repeat length polymorphism in benign prostatic hyperplasia (BPH): correlation with adenoma growth. Prostate 41(4):253-257

9. Partin AW, Page WF, Lee BR, Sanda MG, Miller RN, Walsh PC (1994) Concordance rates for benign prostatic disease among twins suggest hereditary influence. Urology 44(5):646-650

10. Tang J, Yang JC (2009) Etiopathogenesis of benign prostatic hyperplasia. Indian J Urol 25(3):312-317

11. Parsons JK (2007) Modifiable risk factors for benign prostatic hyperplasia and lower urinary tract symptoms: new approaches to old problems. J Urol 178(2):395-401

12. Sanda MG, Beaty TH, Stutzman RE, Childs B, Walsh PC (1994) Genetic susceptibility of benign prostatic hyperplasia. J Urol 152(1):115-119

13. Wang YB, Xie LP, Yuan YG, Zheng XY, Qin J (2007) Differences in the risk factors for clinical benign prostatic hyperplasia between the Mongolian and the Han people. Natl J Androl 13(1):33-36

14. Espinosa $G$ (2013) Nutrition and benign prostatic hyperplasia. Curr Opin Urol 23(1):38-41

15. Hiernaux J (1953) Les caractères physiques des Bashi. Institut Royal Colonial Belge. Section des sciences naturelles et médicales. Mémoirescollection in $8^{\circ}$. Tome XXIII, fasc5 Mém Inst R Colon Belge 5-7:43-47

16. Hiernaux J (1954) Les caractères physiques des populations du Ruanda et de I'Urundi. Institut Royal des Sciences Naturelles de Belgique. Mémoires. Deuxième Série Fasc 52:21-44

17. Hiernaux J (1956) Analyse de la variation des caractères physiques humains en une région de l'Afrique centrale: Ruanda-Urundi et Kivu.
Annales du musée Royal du Congo Belge, Sciences de l'Homme Anthr $3: 1-8$

18. Colle P (1971) Essai de monographie des Bashi. Centre d'étude des langues Africaines 198:2-12, 275-280

19. Biebuyck D (1973) Lega culture. Art, initiation, and moral philosophy among a Central African people. University of California Press, pp 3-11, 16,31

20. Balegamire BJ and Rusimbuka JM (1991) Langue et Culture en Afrique. Le cas des Bahavu du Zaïre. Mélanges à la mémoire d'Aramazani Birusha A. Editions NORAF Ottignies-Kinshasa, pp 23-25

21. Dikonda WL (1971-1972) Les rites chez les Bashi et les Bahavu. Thèse présentée en vue de l'obtention du grade de Docteur en Sciences sociales. Université Libre de Bruxelles, Faculté des Sciences sociales, politiques et économiques, pp 18-20

22. Burume LL (1991) Histoire «Six derniers règnes» antérieurs à 1980 et culture des Bashi au Zaïre. Centre Protestant d'Editions et de Diffusion, CEDI 1:7-10

23. Fontela PC, Winkelmann ER, Ricardo P, Viecili N (2017) Study of conicity index, body mass index and waist circumference as predictors of coronary artery disease. Rev Port Cardiol 36(5):357-364

24. Shenoy U, Jagadamba J (2017) Influence of central obesity assessed by Conicity index on lung age in young adults. J Clin Diagn Res 11(4):CC09-CC12

25. Chokkalingam AP, Yeboah ED, De Marzo A, Netto G, Yu K, Biritwum RB, Tettey $Y$ et al (2012) Prevalence of BPH and lower urinary tract symptoms in West Africans. Prostate Cancer Prostatic Dis 15:170-176

26. Chen WC, Yang CC, Chen GY, Wu MC, Sheu HM, Tzai TS (2004) Patients with a large prostate show a higher prevalence of androgenetic alopecia. Arch Dermatol Res 296:245-249

27. Cózar-Olmoa JM, Hernández-Fenández C, Minana-López B, AmónSesmerod JH, Montlleó-Gonzáleze M, Rodríguez-Antolínf A, CaballeroMartínezg F (2012) Consensus on the clinical impact of the new scientific evidence available on benign prostatic hyperplasia. Actas Urol Esp 36(5):265-275

28. Jin B, Turner L, Zhou Z, Handelson DJ (1999) Ethnicity and migration as determinants of human prostate size. J Clin Endocrinol Metab 84:3613-3619

29. Luo J, Dunn T, Ewing C, Sauvageot J, Chen Y, Trent J et al (2002) Gene expression signature of benign prostatic hyperplasia revealed by cDNA microarray analysis. Prostate 51:189-200

30. Patel ND, Parsons JK (2014) Epidemiology and etiology of benign prostatic hyperplasia and bladder outlet obstruction. Indian J Urol 30(2):170-176

31. Pearson J, Lei H, Beaty TH, Wiley KE, Isaacs SD, Isaacs WB et al (2003) Familial aggregation of bothersome benign prostatic hyperplasia symptoms. Urology 61:781-785

32. Mehta V, Vezina CM (2011) Potential protective mechanisms of aryl hydrocarbon receptor (AHR) signaling in benign prostatic hyperplasia. Differentiation 82(4-5):211-219

33. Ejike CECC (2008) Ezeanyika LUS. Metabolic syndrome in sub-Saharan Africa: "smaller twin" of a region's prostatic diseases? pp 909-920

34. Parsons JK (2011) Lifestyle factors, benign prostatic hyperplasia, and lower urinary tract symptoms. Curr Opin Urol 21(1):1-4

35. Bravi F, Bosetti C, Dal Maso L, Talamini R, Montella M, Negri E et al (2006) Food groups and risk of benign prostatic hyperplasia. Urology 67:73-79

36. Bravi F, Bosetti C, Dal Maso L, Talamini R, Montella M, Negri E et al (2006) Macronutrients, fatty acids, cholesterol, and risk of benign prostatic hyperplasia. Urology 67:1205-1211

\section{Publisher's Note}

Springer Nature remains neutral with regard to jurisdictional claims in published maps and institutional affiliations. 